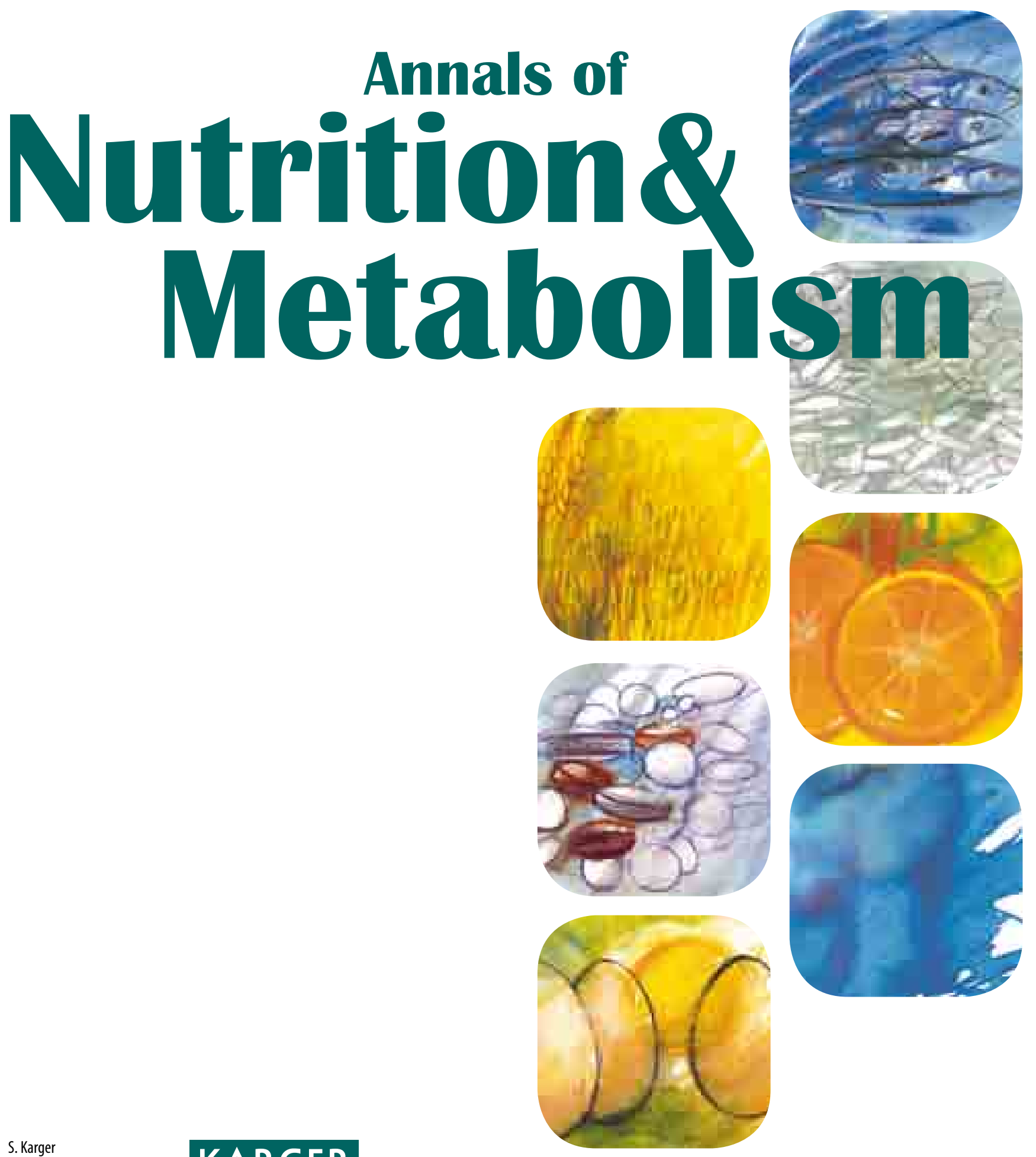

Medical and Scientific Publishers Basel · Freiburg · Paris .

London · New York .

New Delhi · Bangkok · Beijing

Tokyo - Kuala Lumpur .

Singapore $\cdot$ Sydney 


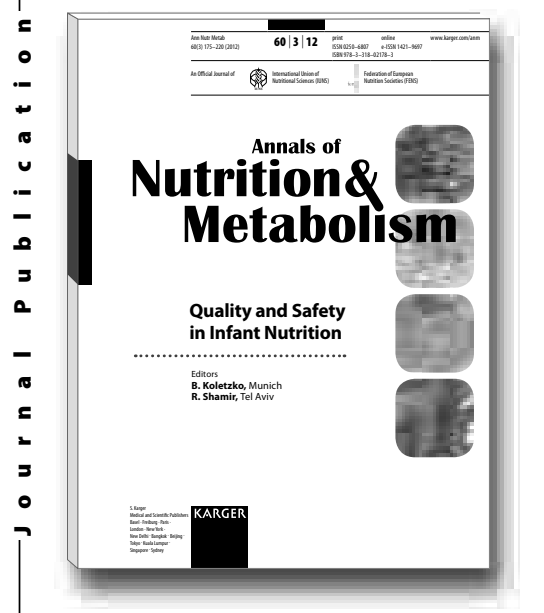

\title{
Quality and Safety in Infant Nutrition
}

\author{
Editors \\ B. Koletzko \\ R. Shamir
}

\section{Contents \\ Quality and Safety Aspects of Infant Nutrition: Koletzko, B.; Shamir, R.; Ashwell, M.; on behalf of the Early Nutrition Academy (ENA) and the European Society for Paediatric Gastroenterology, Hepatology and Nutrition (ESPGHAN)}

Thiamine-Deficient Infant Formula: What Happened and What Have We Learned? Shamir, $\boldsymbol{R}$.

Current Safety Standards in Infant Nutrition - A European Perspective: Hernell, 0 .

Safety Standards in Infant Nutrition: A United States Perspective: Bier, D.M.

Preclinical Assessment of Infant Formula: Lönnerdal, B.
Clinical Safety Assessment of Infant Nutrition: Fewtrell, M.S.

The Role of Systematic Data Reviews in Safety Assessment of Infant Nutrition: Szajewska, $\mathrm{H}$.

Quality Control throughout the Production Process of Infant Food: Hamrin, P.; Hoeft, B.

Safety Aspects in Preparation and Handling of Infant Food: Turck, $D$.

Non-Breast Milk Feeding in Developing Countries: Challenge from Microbial and Chemical Contaminants: Weisstaub, G.; Uauy, $\boldsymbol{R}$.
Quality and Safety in Infant Nutrition Editors: Koletzko, B. (Munich); Shamir, R. (Tel Aviv) 46 p., 3 fig., 4 tab., soft cover, 2012 CHF 29.- / EUR 24.- / USD 34.00 Prices subject to change

EUR price for Germany, USD price for USA only ISBN 978-3-318-02178-3

e-ISBN 978-3-318-02179-0

Annals of Nutrition and Metabolism Vol. 60, No. 3 (2012) Included in subscription
Please send:

copy/ies

Postage and handling free with prepayment

Please charge to my credit card

- $\square$ American Express $\square$ Diners

ᄂ $\square$ MasterCard

- Card No.

$\boldsymbol{v}$

ס

CVV/CVC

( 3 digits in the signature field on the back of Visa and MasterCard)

$\square$ Check enclosed $\square$ Please bill me

Orders may be placed with any bookshop, subscription agency, directly with the publisher or through a Karger distributor.
Fax: +41 613061234

S. Karger AG, P.O. Box, CH-4009 Basel (Switzerland) E-Mail orders@karger.ch, www.karger.com

Name/Address: 
An Official Journal of

International Union of Nutritional Sciences (IUNS)

\section{IUNS Editorial Representative}

I. Elmadfa, Vienna

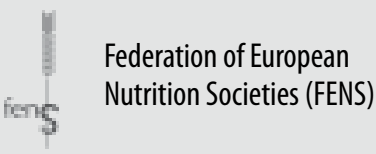

FENS Editorial Representative

D. Lairon, Marseilles

European Neutraceutical Association (ENA)

ENA Editorial Representative

M. Lamprecht, Graz

Deutsche Gesellschaft für

Ernährung (DGE)

\section{DGE Editorial Reresentative}

H. Oberritter, Bonn
An Official Journal of

International Union of Nutritional Sciences (IUNS)

Federation of European Nutrition Societies (FENS)

European Neutraceutical Association (ENA)

Deutsche Gesellschaft für Ernährung (DGE)

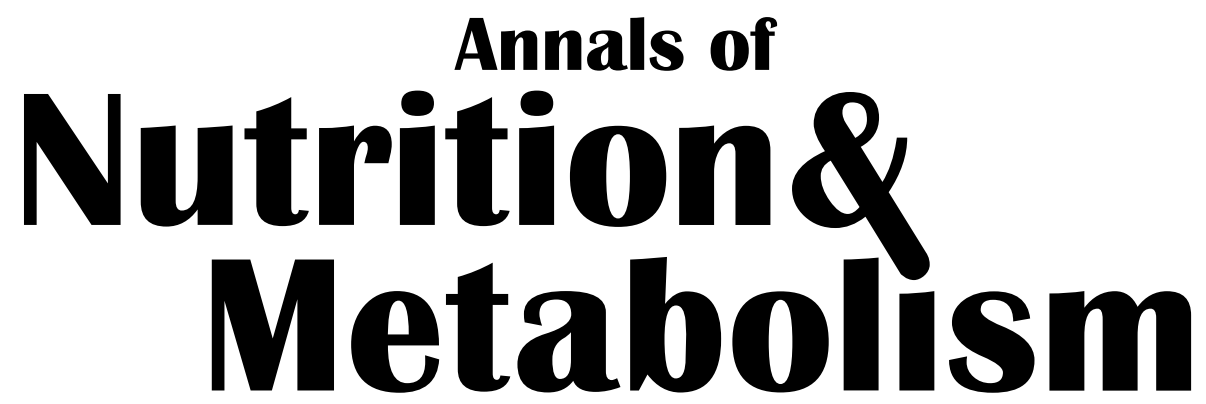

Founded 1959 as 'Nutritio et Dieta' by E. Azerad, H. Kapp and J. Trémolières. Continued by A. Wretlind (1961-1969). Continued by N. Zöllner (1970-1990) as 'Nutrition and Metabolism' (1970-1980), since 1980 integrating 'Annales de la Nutrition et de l'Alimentation', continued as 'Annals of Nutrition and Metabolism'. Continued by G. Wolfram (1991-1999), Continued by I. Elmadfa (2000-2010)
Editor

B. Koletzko, Munich

\section{Assistant Editor}

B. Kessler, Munich

Associate Editors

P.S.W. Davies, Brisbane, Qld.

L. de Groot, Wageningen

G. Desoye, Graz

A. Gil, Granada

J. Heinrich, Neuherberg

R. Meier, Liestal

S. Nagata, Izunokuni

L. Poston, London

M. Schulze, Nuthetal

M.B. Zimmermann, Zurich

\section{Editorial Board}

A. Astrup, Copenhagen

A. Berg, Freiburg

Z.A. Bhutta, Karachi

S.C. Bischoff, Stuttgart

F. Branca, Rome

R. Brigelius-Flohé, Nuthetal

P.C. Calder, Southampton

S. Carlson, Kansas City, Kan.

I. Cetin, Milan

R.J. Deckelbaum, New York, N.Y.

T. Decsi, Pécs
C.J. Field, Edmonton

K. Godfrey, Southampton

R. Hakkak, Little Rock, Ark.

W.S. Harris, Sioux Falls, S. Dak.

H. Hauner, Munich

M. Hernández-Triana, Havana

H. Heseker, Paderborn

E. Hypponen, London

J. Kopecky, Prague

M. Krawinkel, Giessen

M. Lamprecht, Graz

W. Langhans, Zurich

J. Linseisen, Heidelberg

O. Ljungqvist, Örebro

J.A. Martinez, Pamplona

H.J. McArdle, Aberdeen

Y. Naito, Kyoto

P.W. Nathanielsz, San Antonio, Tex.

H. Oberritter, Bonn

R. Saffery, Parkville, Vic.

W.H.M. Saris, Maastricht

L. Serra-Majem, Las Palmas de Gran Canaria

C. Sieber, Nürnberg

A.P. Simopoulos, Washington, D.C.

P. Singer, Petah Tikva

N.W. Solomons, Guatemala City

P. Stehle, Bonn

I. Thorsdottir, Reykjavik

K. Tontisirin, Nakhon Pathom

R. Uauy, Santiago

S. Villalpando, Cuernavaca Morelos

T. Yoshikawa, Kyoto

A. Zittermann, Bad Oeynhausen

\section{KARGER}

$\begin{array}{ll}\begin{array}{l}\text { Printed in Switzerland } \\ \text { on acid-free and non-aging } \\ \text { paper (ISO 9706) by }\end{array} & \begin{array}{l}\text { Appears every 6 weeks: } \\ \text { 2 volumes per year } \\ \text { (8 issues) }\end{array} \\ \text { Reinhardt Druck, Basel } & \end{array}$




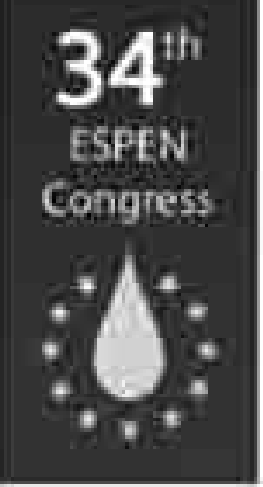

THE FUROPEAN SOCIE TY FOH

CLISICAL

NUTHITION AND

METABOLISM

\section{ESPEN Congress on}

Clinical Nutrition \& Metabolism

\section{Barcelona, Spain}

8-11 September 2012

\section{Achieving Goals in Nutrition}

Fat noe hifintatiog poinc custart. the Congress Secietinat ESPEN 2012 cio Ma Saisse SA has de fyon 75 :

1211 Gewa 13 Switedtand

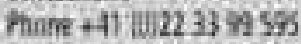

fa +41 Donzosi

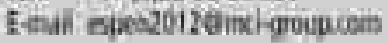

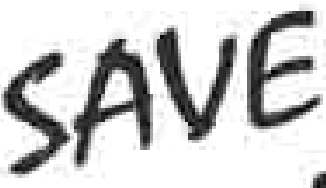

THE

$\therefore \therefore$

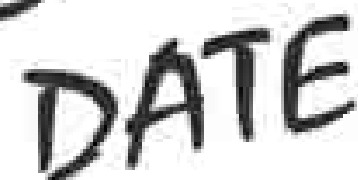

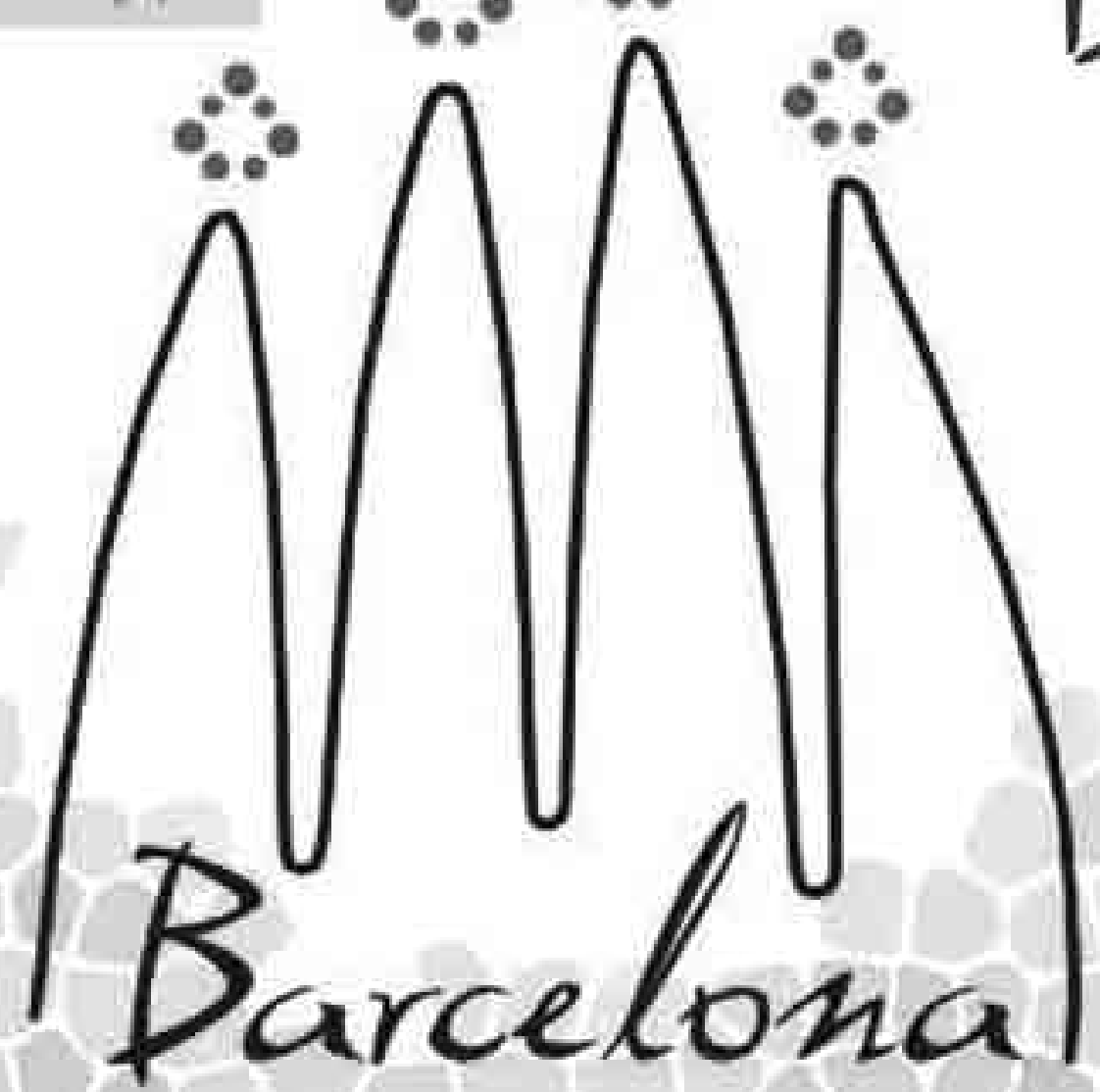




\section{Nutrition\& Metabolism}

\section{Contents}

Original Papers

1 Effect of Intraoperative Amino Acid Infusion on Blood Glucose under General Anesthesia Combined with Epidural Block

Zhong, J.; Ge, S.J.; Zhuang, X.F.; Cang, J.; Xue, Z.G. (Shanghai)

7 Reduced Folate, Increased Vitamin $B_{12}$ and Homocysteine Concentrations in Women Delivering Preterm

Dhobale, M.; Chavan, P.; Kulkarni, A.; Mehendale, S.; Pisal, H.; Joshi, S. (Pune)

15 Effect of the Intake of Resveratrol, Resveratrol Phosphate, and Catechin-Rich Grape Seed Extract on Markers of Oxidative Stress and Gene Expression in Adult Obese Subjects

De Groote, D. (Sprimont); Van Belleghem, K. (Wetteren); Devière, J. (Brussels); Van Brussel, W. (Wetteren); Mukaneza, A. (Sprimont); Amininejad, L. (Brussels)

25 Erythrocyte $n-3$ Polyunsaturated Fatty Acid and Seafood Intake Decrease the Risk of Depression: Case-Control Study in Korea

Park, Y.; Kim, M.; Baek, D.; Kim, S.-H. (Seoul)

32 Increased Ferritin Concentrations Correlate with Insulin Resistance in Female Type 2 Diabetic Patients

Yu, F.-J.; Huang, M.-C.; Chang, W.-T. (Kaohsiung); Chung, H.-F. (Kaohsiung/Brisbane, Qld.); Wu, C.-Y.; Shin, S.-J. (Kaohsiung); Hsu, C.-C. (Zhunan/Taichung)

41 Association between Thigh Muscle Development and the Metabolic Syndrome in Adults

Londoño, F.J.; Calderón, J.C.; Gallo, J. (Medellín)

47 Effects of Medical Nutrition Therapy on Body Fat and Metabolic Syndrome Components in Premenopausal Overweight Women

Lim, H. (Seoul/Baltimore, Md.); Son, J.-Y. (Yongin); Choue, R. (Seoul/Yongin)
57 Effects of Xylitol on Blood Glucose, Glucose Tolerance, Serum Insulin and Lipid Profile in a Type 2 Diabetes Model of Rats

Islam, M.S.; Indrajit, M. (Durban)

65 Nutritional Screening Model in Tertiary Medical Unit in Croatia

Pavic, T.; LJubicic, N.; Stojsavljevic, S.; Krznaric, Z. (Zagreb)

70 Basal GLP-1 Levels in Morbidly Obese Patients following Biliopancreatic Diversion Surgery

de Luis, D.; Pacheco, D.; Conde, R.; Primo, D.; Aller, R.; Izaola, O. (Valladolid)

74 Cholecalciferol Supplementation in Chronic Kidney Disease: Restoration of Vitamin D Status and Impact on Parathyroid Hormone

Garcia-Lopes, M.G.; Pillar, R.; Kamimura, M.A.; Rocha, L.A.; Canziani, M.E.F.; Carvalho, A.B.; Cuppari, L. (São Paulo)

6 Erratum
83 The Official FENS Calendar
84 FENS News
85 IUNS News
87 ENA News




\section{IUNS $20^{\text {th }}$ International Congress of Nutrition}

GRANADA (SPAIN) SEPTEMBER 15-20, 2013 "Joining Cultures Through Nutrition"

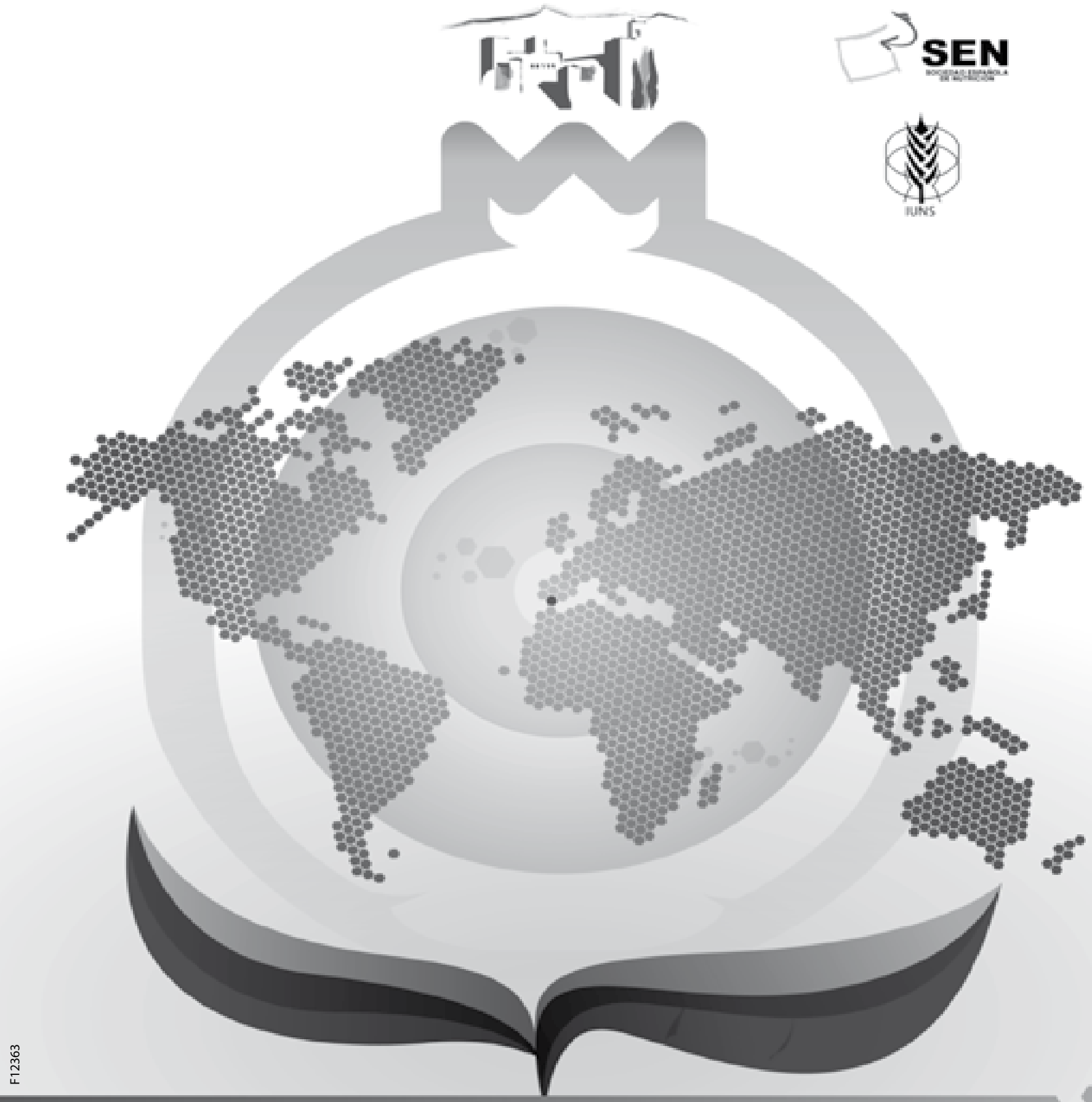

\section{www.icn2013.com}

Technical Secretariat:

VIAJES Ć:IBERIA
Viajes Iberia Congresos

Edif. Orizonia - C/ Plaça d' Europa, $17-191^{\text {st }}$ Floor 08908 Hospitalet de Llobregat - Barcelona - Spain T. $+34935101005-$ F. +34935101009 e-mail: icn2013@viajesiberia.com 


\section{Nutrition\& Metabolism}

ISSN Print Edition: 0250-6807

ISSN Online Edition: 1421-9697

Journal Homepage: www.karger.com/anm

Publication Data: 'Annals of Nutrition and Metabolism' is published 8 times a year. Volumes 60 and 61 , each with 4 issues, appear in 2012 .

Copyright: (c) 2012 S. Karger AG, Basel (Switzerland). All rights reserved. No part of this publication may be translated into other languages, reproduced or utilized in any form or by any means, electronic or mechanical including photocopying, recording, microcopying, or by any information storage and retrieval system, without permission in writing from the publisher or, in the case of photocopying, direct payment of a specified fee to the Copyright Clearance Center.

Disclaimer: The statements, opinions and data contained in this publication are solely those of the individual authors and contributors and not of the publisher and the editor(s). The appearance of advertisements in the journal is not a warranty, endorsement, or approval of the products or services advertised or of their effectiveness, quality or safety. The publisher and the editor(s) disclaim responsibility for any injury to persons or property resulting from any ideas, methods, instructions or products referred to in the content or advertisements.
Subscription Rates: Subscriptions run for a full calendar year. Prices are given per year. Personal subscription:

Print or Online

CHF 971.-

EUR 776.-

USD 943.00

Print+Online combined CHF 1067.-

EUR 852.-

postage and handling (added to print and print+online)

CHF 54.40 Europe, CHF 80.- Overseas

EUR 41.60

USD 75.20

Institutional subscription:

Print or Online

Print+Online combined

CHF 3236.-

EUR 2588.-

CHF 3560.-

postage and handling (added to print and print+online)

CHF 68.- Europe, CHF 100.- Overseas

EUR 52.-

USD 94.00

Airmail surcharge: CHF 68.- / USD 64.00

Discount subscription prices:

Please enquire about reduced rates for members of affiliated societies.
Back Volumes and Single Issues: Information on availability and prices of single print issues and print or electronic back volumes can be obtained from Customer Service at service@karger.ch.

Bibliographic Indices: This journal is regularly listed in bibliographic services, including Current Contents ${ }^{\circledR}$ and PubMed/MEDLINE.

Photocopying: This journal has been registered with the Copyright Clearance Center (CCC), as indicated by the code appearing on the first page of each article. For readers in the US, this code signals consent for copying of articles for personal or internal use, or for the personal or internal use of specific clients, provided that the stated fee is paid per copy directly to

Copyright Clearance Center Inc.

222 Rosewood Drive

Danvers, MA 01923 (USA)

A copy of the first page of the article must accompany payment. Consent does not extend to copying for general distribution, for promotion, for creating new works, or for resale. In these cases, specific written permission must be obtained from the copyright owner,

S. Karger AG, P.O. Box

CH-4009 Basel (Switzerland).

\section{Subscription Orders:}

Orders can be placed at agencies, bookstores, directly with the Publisher

\section{S. Karger AG}

Medical and Scientific Publishers

P.O. Box

$\mathrm{CH}-4009$ Basel

Switzerland

(for courier services only:

Allschwilerstrasse 10

CH-4055 Basel)

: +416130611 11

f: +41613061234

e: karger@karger.ch

w: www.karger.com or further Karger offices

or representatives:

Germany

S. Karger GmbH

79095 Freiburg

Deutschland

(Hausadresse: Wilhelmstrasse 20A

79098 Freiburg)

$\mathrm{t}: \quad+49761452070$

$\mathrm{f:} \quad+497614520714$

e: information@karger.de

w: www.karger.de

Japan

Karger Japan, Inc.

Shiba Daimon Asahi Bldg. 2F

1-2-23 Shiba Daimon

Minato-ku

Tokyo 105-0012

Japan

t: +81364356242

f: +81364356244

e: publisher@karger.jp

w: www.karger.jp

Change of Address:

Both old and new address should be sent

to the subscription source.

USA

S. Karger Publishers, Inc.

26 West Avon Road

P.O. Box 529

Unionville, CT 06085

USA

Toll free: +18008285479

t: +18606757834

$\mathrm{f}: \quad+18606757302$

e: karger@snet.net

France

Librairie Médi-Sciences Sar

36, bd de Latour-Maubourg

75007 Paris

France

t: $+33(0) 145514258$

f. $+33(0) 145560780$

e: librairie@medi-sciences.f

e: librairie@medi-sciences.

Gulf Council Countries, Iran,

Middle East, North Africa, Turkey

Trans Middle East International

Distribution Co. Ltd.

KaSha

134 Queen Rania Al Abdullah Street

Jordan Trade Center Bldg. 3rd Floor

P.O. Box 2376

Amman 11953

Jordan

$\mathrm{t}:+96265153467$

f: +96265153472

e: info@kasha.cc

w: www.KaShaonline.com
South East Asia, China and Taiwan

Karger Regional Office (Malaysia)

CEO Suite Kuala Lumpur

Quill 7, 27th Floor

Jalan Stesen Sentral 5

KL Sentral

Kuala Lumpur 50470

Malaysia

t: +60327766803

f: +60327766999

e: service@karger.cn; r.chew@karger.cn

Karger China

10th Floor, Twin Towers (East)

B12 Jianguomenwai Avenue

Beijing 100022

$\mathrm{t}:+861051235033$

f: +861051235122

e: service@karger.cn; r.chew@karger.cn

w: www.karger.cn

India, Bangladesh, Sri Lanka

Medscience India

Plot No. 17, Yusuf Sarai Market

B.L. Glass Building, 2nd Floor

Sri Aurobindo Marg

New Delhi 110016

India

t: +911146029633

f: +911146029634

c: +919891052128

e: medsci.india@gmail.com

\section{KARGER}

Fax +41 613061234

E-Mail karger@karger.ch

www.karger.com
(C) 2012 S. Karger AG, Basel

The Journal Home Page is available at:

www.karger.com/anm 


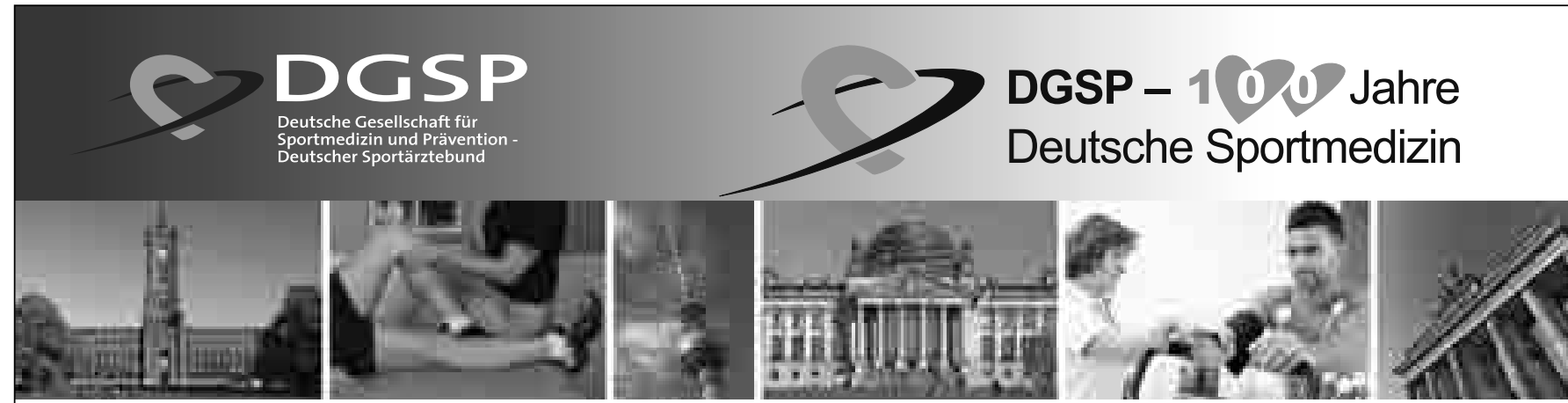

\section{Jahre \\ Deutsche Sportmedizin 100 Years of German Sports Medicine}

Sportmedizin im Wandel - Wandel durch Sportmedizin Sports Medicine in Change - Change through Sports Medicine

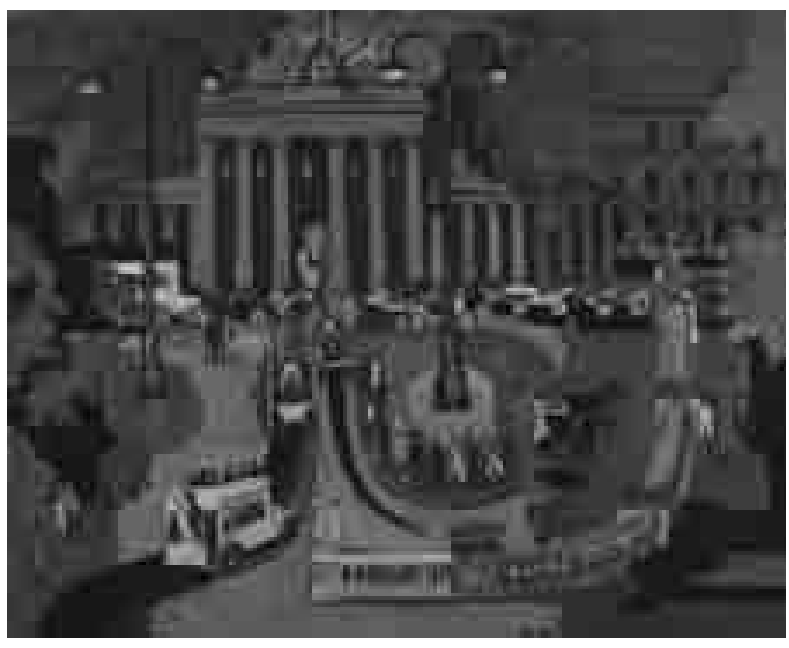

\section{Jubiläumskongress}

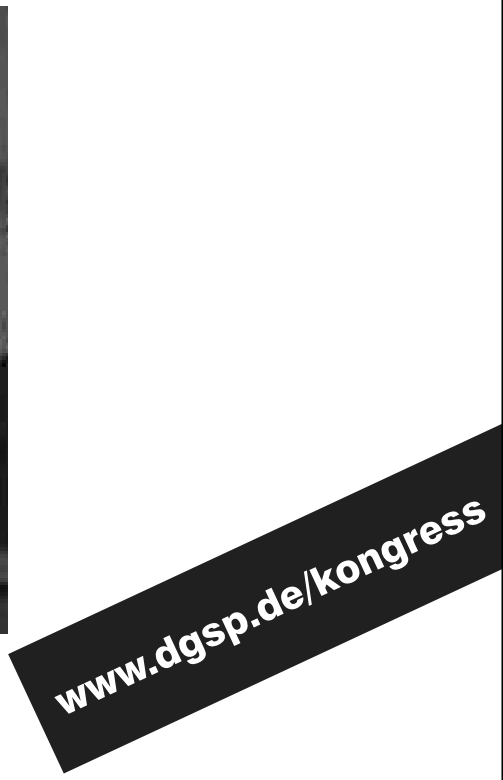

4. - 6. Oktober 2012 - Estrel Convention Center, Berlin

Unter der Schirmherrschaft von FIMS und EFSMA

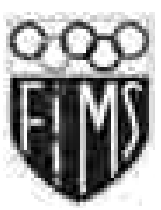

COME D

KONGRESSE

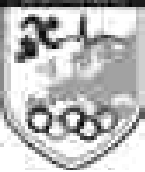




\section{Contents}

See the journal website for contents

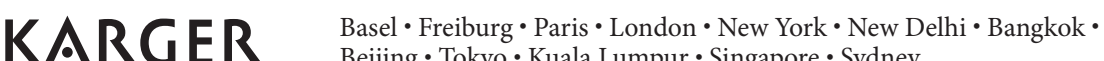
Beijing $\cdot$ Tokyo $\cdot$ Kuala Lumpur $\cdot$ Singapore $\cdot$ Sydney 


\section{Nutrition \& Metabolism}

\section{Aims and Scope}

The journal focuses on human nutrition and metab olism and related areas, including experimental studies and basic science that can inform human nutrition science. We welcome manuscripts describing observational and intervention studies as well as basic science reports on the topics of foods, diets and dietary supplements, nutrigenomics and genetics related to metabolism, on energy metabolism, macro- and micronutrients including vitamins and minerals, biofunctional compounds, dietetics, obesity, clinical nutrition social sciences and health economy as related to nutrition and metabolism and nutrition policy. Laboratorybased science may include descriptions of relevant experimental models. In addition to Original Papers, the journal will publish Review Articles on topical subjects, Systematic Reviews, short Commentaries and Viewpoint articles that may address current controversies, short Meeting Reports, Letters to the Editor, and Announcements/Society News. The journal will also publish Supplements with proceedings from internationally relevant conferences on nutrition and metabolism.

\section{Submission}

Manuscripts written in English are considered and should be submitted online at

\section{www.karger.com/anm}

Authors may suggest up to four Referees who have expert knowledge on the subject. Suggested Referees should not be from the same institution, not have published with the authors during the last 5 years, and should not be prejudiced.

Should you experience problems with your submission, please contact
Prof. Dr. B. Koletzko
Div. Metabolic and Nutritional Medicine
Dr. von Hauner Children's Hospital
Ludwig-Maximilians-University of Munich
Lindwurmstrasse 4
D-80337 Munich (Germany)
Tel. + +498951602826
E-Mail ANM@med.uni-muenchen.de

\section{Conditions}

All manuscripts are subject to editorial review. Manuscripts are received with the explicit understanding that they are not under simultaneous consideration by any other publication. Submission of an article for publication implies transfer of the copyright from the author to the publisher upon acceptance. Accepted papers become the permanent property of 'Annals of Nutrition and Metabolism' and may not be reproduced by any means, in whole or in part, without the written consen of the publisher. It is the author's responsibility to obtain permission to reproduce illustrations, tables, etc. from other publications.

\section{Types of Articles}

The journal consists of the following sections:

Original Papers are full-length research papers which will be considered for the journal. Articles cover topics relevant to clinical studies. Basic and experimenta work appear only if directly related to clinical issues (max. 2,500 words)
Review Articles/Systematic Reviews are comprehensive, state-of-the-art papers of important clinical problems. Reviews may be invited by the Editor or they may be unsolicited views (max. 5,000 words).

Commentaries and Viewpoint of an editorial nature may be submitted to the journal. In these communications, usual manuscript subdivisions do not apply, and a summary statement is not needed; however, a very brief reference list may be included (max. 500 words).

Meeting Reports are brief summaries of scientific meetings in the field of nutrition and metabolism. Authors should write a letter to the Editors inquiring about potential interest before submitting the paper. (max. 1,500 words).

Letters to the Editor are encouraged if they directly concern articles previously published in this journal or clinical subjects related to the matters discussed. The editor reserves the right to submit copies of such letters to the authors of the articles concerned prior to publication in order to permit them to respond in the same issue of the journal (max. 500 words).

Editorials are usually invited by the Editor (max. 1,000 words). Please send suggestions to the Editor.

Authors are referred to the uniform requirements for manuscripts submitted to biomedical journals (http://www.icmje.org/ethical_1author.html) for further guidance.

\section{Conflicts of Interest}

Authors are required to disclose any sponsorship or funding arrangements relating to their research and all authors should disclose any possible conflicts of interest. Conflict of interest statements will be published at the end of the article.

\section{Ethics}

Published research must comply with the guidelines for human studies and animal welfare regulations. Authors should state that subjects have given their informed consent and that the study protocol has been approved by the institute's committee on human research. Further, they should also state that animal experiments conform to institutional standards.

\section{Plagiarism Policy}

Plagiarism is misrepresenting somebody else's published intellectual work-product as your own (Note, this definition excludes 'self-plagiarism'). In short, it is a misuse of source material. Whether intentional or unintentional, plagiarism is a serious violation of the Annals of Nutrition and Metabolism policy. Periodically, manuscripts are screened for plagiarism and if your manuscript is found to be consistent with what the Editors define $e^{\star}$ as plagiarism prior to review of the manuscript then

1) it will be rejected without review and the author(s) notified as such with a chance for rebuttal.

If a manuscript is found to contain evidence of plagiarism after acceptance and/or publication then

1) the author(s) will be notified, as in the previous situation, and offered a chance for rebuttal.

If the rebuttal arguments are not found to be satisfactory, as judged by the Editors, the manuscript will be rejected and the author sanctioned from publishing additional papers in the Journal for a period to be determined by the Editorial Board. The period of sanction imposed is dependent on the magnitude of plagiarism with a minimum sanction of one year.
If a manuscript already published in the Journal is found to exhibit evidence of plagiarism as defined by the Editors ${ }^{\star}$, then we will request a retraction.

${ }^{\star}$ Definition of plagiarism - a $25 \%$ similarity in the Results or Discussion that exactly reproduces another paper.

\section{Arrangement}

Title page: The first page of each paper should indicate the title, the authors' names, the institute where the work was conducted, and a short title for use as running head.

Full address: The exact postal address of the corresponding author complete with postal code must be given at the bottom of the title page. Please also supply phone and fax numbers, as well as e-mail address.

Key words: For indexing purposes, a list of 3-10 key words in English is essential.

Abstract: Each paper needs an abstract of up to 200 words. It should be structured as follows:

Background/Aims: What is the major problem that prompted the study?

Methods: $\quad$ How was the study performed?

Results: Most important findings?

Conclusion: Most important conclusion?

Footnotes: Avoid footnotes.

Tables and illustrations: Tables are part of the text. Place them at the end of the text file. Illustration data must be stored as separate files. Do not integrate figures into the text. Electronically submitted $\mathrm{b} / \mathrm{w}$ half tone and color illustrations must have a final resolution of $300 \mathrm{dpi}$ after scaling, line drawings one of 800-1,200 dpi.

Color illustrations

Online edition: Color illustrations are reproduced free of charge. In the print version, the illustrations are reproduced in black and white. Please avoid referring to the colors in the text and figure legends.

Print edition: Up to 6 color illustrations per page can be integrated within the text at CHF 800.- per page.

References: In the text, identify references by Arabic numerals [in square brackets]. Material submitted for publication but not yet accepted should be noted as 'unpublished data' and not be included in the reference list. The list of references should include only those publications which are cited in the text. Do not alphabetize; number references in the order in which they are first mentioned in the text. The surnames of the authors followed by initials should be given. There should be no punctuation other than a comma to separate the authors. Preferably, please cite all authors. Abbreviate journal names according to the Index Medicus system. Also see International Committee of Medical Journal Editors: Uniform requirements for manuscripts submitted to biomedical journals (www.icmje.org).

\section{Examples}

(a) Papers published in periodicals: Chatel J-M, Bernard $\mathrm{H}$, Orson FM: Isolation and characterization of two complete Ara h 2 isoforms cDNA. Int Arch Allergy Immunol 2003;131:14-18.

(b) Papers published only with DOI numbers:

Theoharides TC, Boucher W, Spear K: Serum interleukin-6 reflects disease severity and osteoporosis in mastocytosis patients. Int Arch Allergy Immunol DOI: $10.1159 / 000063858$.

(c) Monographs: Matthews DE, Farewell VT: Using and Understanding Medical Statistics, ed 3, revised. Basel, Karger, 1996.

\section{KARGER}

Fax +41613061234

E-Mail karger@karger.ch

www.karger.com
(C) 2012 S. Karger AG, Basel

www.karger.com/anm_Guidelines 


\title{
Annals of \\ Nutrition\& Metabolism
}

(d) Edited books: DuBois RN: Cyclooxygenase-2 and colorectal cancer; in Dannenberg AJ, Dubois RN (eds): COX-2. Prog Exp Tum Res. Basel, Karger, 2003, vol 37, pp 124-137.

Reference Management Software: Use of EndNote is recommended for easy management and formatting of $\mathrm{ci}$ tations and reference lists.

\section{Digital Object Identifier (DOI)}

S. Karger Publishers supports DOIs as unique identifiers for articles. A DOI number will be printed on the title page of each article. DOIs can be useful in the future for identifying and citing articles published online without volume or issue information. More information can be found at www.doi.org.

\section{Supplementary Material}

Supplementary material is restricted to additional data that are not necessary for the scientific integrity and conclusions of the paper. Please note that all supplementary files will undergo editorial review and should be submitted together with the original manuscript The Editors reserve the right to limit the scope and length of the supplementary material. Supplementary material must meet production quality standards for Web publication without the need for any modification or editing. In general, supplementary files should not exceed $10 \mathrm{MB}$ in size. All figures and tables should have titles and legends and all files should be supplied separately and named clearly. Acceptable files and for- mats are: Word or PDF files, Excel spreadsheets (only if the data cannot be converted properly to a PDF file), and video files (.mov, .avi, .mpeg)

\section{Author's Choice ${ }^{\mathrm{TM}}$}

Karger's Author's Choice ${ }^{\mathrm{TM}}$ service broadens the reach of your article and gives all users worldwide free and full access for reading, downloading and printing at www.karger.com. The option is available for a onetime fee of CHF 3000.-, which is a permissible cost in grant allocation. More information can be found at www.karger.com/authors_choice.

\section{NIH-Funded Research}

The U.S. National Institutes of Health (NIH) mandates under the NIH Public Access Policy that final, peer-reviewed manuscripts appear in its digital database within 12 months of the official publication date. As a service to authors, Karger submits the final version of your article on your behalf to PubMed Central. For those selecting our premium Author's Choice ${ }^{\mathrm{TM}}$ service, we will send your article immediately upon publishing, accelerating the accessibility of your work without the usual embargo. More details on NIH's Public Access Policy is available at http://publicaccess.nih.gov/FAQ.htm\#a 1

\section{Self-Archiving}

Karger permits authors to archive their pre-prints (i.e. pre-refereeing) or post-prints (i.e. final draft post-refereeing) on their personal or institution's servers, pro- vided the following conditions are met: Articles may not be used for commercial purposes, must be linked to the publisher's version, and must acknowledge the publisher's copyright. Authors selecting Karger's Author's Choice ${ }^{\mathrm{TM}}$ feature, however, are also permitted to archive the final, published version of their article, which includes copyediting and design improvements as well as citation links.

\section{Page Charges}

There are no page charges for papers of 3 or fewer printed pages (including tables, illustrations and references). Each additional complete or partial page is charged to the author at CHF 325.-. The allotted size of a paper is equal to approx. 10 manuscript pages (including tables, illustrations and references).

Proofs

Unless indicated otherwise, proofs are sent to the firstnamed author and should be returned with the least possible delay. Alterations made in proofs, other than the correction of printer's errors, are charged to the author

\section{Reprints}

Order forms and a price list are sent with the proofs. Orders submitted after the issue is printed are subject to considerably higher prices.
Series Editor

Simopoulos, A.P. (Washington, D.C.)

World Review of Nutrition and Dietetics

ISSN 0084-2230

e-ISSN 1662-3975

Listed in bibliographic services, including Current Contents ${ }^{\circledR}$, Index Medicus, Reference Update Biological Abstracts.

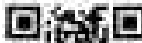

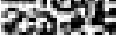

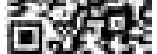

Read it online: www.karger.com/wrund

\section{World Review of Nutrition and Dietetics}

\begin{abstract}
'... commendably high standards of scientific merit and literary clarity ... The publications in this series can help substantially to keep everyone interested in nutrition well abreast of recent progress.' British Medical Journal
\end{abstract}

Volumes in this series consist of exceptionally thorough reviews on topics selected as either fundamental to improved understanding of human and animal nutrition, useful in resolving present controversies, or relevant to problems of social and preventive medicine that depend for their solution on progress in nutrition. Many of the individual articles have been judged as among the most comprehensive reviews ever published on the given topic. Since the first volume appeared in 1959, the series has earned repeated praise for the quality of its scholarship and the reputation of its authors.

Vol. 102: Healthy Agriculture,
Healthy Nutrition,
Healthy People
Editor: Simopoulos, A.P.
(Washington, D.C.)
XII + 274 p., 45 fig., 47 tab.,
hard cover, 2011
CHF 228.- / EUR 190.- / USD 268.00
ISBN 978-3-8055-9779-1
--ISBN 978-3-8055-9780-7

Vol. 101: Personalized Nutrition: Translating Nutrigenetic/Nutrigenomic Research into Dietary Guidelines

Editors: Simopoulos, A.P. (Washington, D.C.); Milner, J.A (Potomac, Md.)

$X X+180$ p., 19 fig., 15 tab.

hard cover, 2010 CHF 228.- / EUR 190.- / USD 268.00 ISBN 978-3-8055-9427-1 e-ISBN 978-3-8055-9428-8

\author{
Vol. 100: A Balanced Omega-6/ \\ Omega-3 Fatty Acid Ratio, \\ Cholesterol and Coronary \\ Heart Disease \\ Editors: Simopoulos, A.P. \\ (Washington, D.C.); De Meester, F. \\ (Waterloo) \\ $X V I+126$ p., 19 fig., 25 tab. \\ hard cover, 2009 \\ CHF 156 - / EUR 130 - / USD 184.00 \\ ISBN 978-3-8055-9224-6 \\ e-ISBN 978-3-8055-9225-3
}

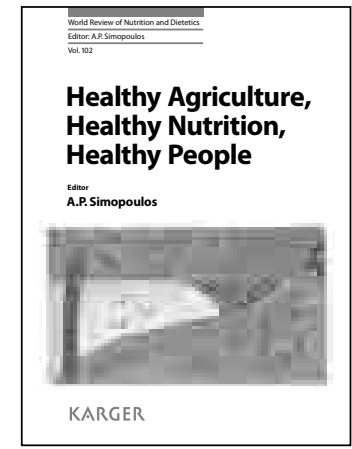

Vol. 99: Omega-3 Fatty Acids the Brain and Retina

Editors: Bazan, N.G. (New Orleans, La.); Simopoulos, A.P. (Washington, D.C.) XII + 164 p., 20 fig., 19 tab. hard cover, 2009 CHF 219.- / EUR 183.- / USD 258.00 ISBN 978-3-8055-9019-8 e-ISBN 978-3-8055-9020-4

\section{KARGER}

Fax +41 613061234 E-Mail karger@karger.ch www.karger.com
Prices subject to change

EUR price for Germany, USD price for USA only 


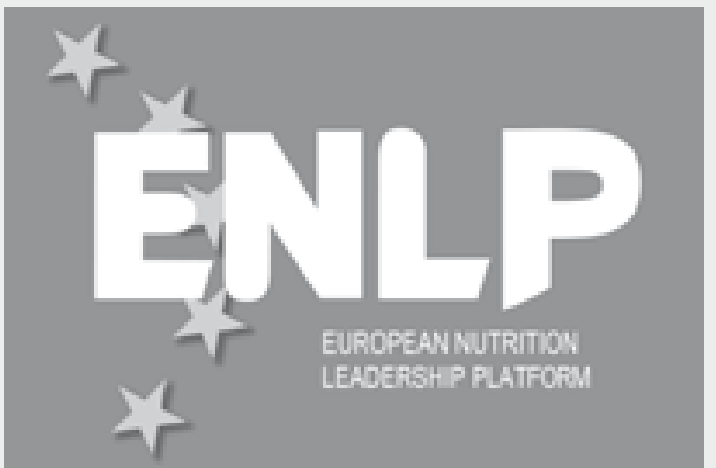

\section{General information}

The aim of the European Nutrition Leadership Platform (ENLP) is to assist in the development of leaders in the field of human nutrition in Europe.

\section{ENLP's vision: 'To develop, inspire and connect leaders within Europe to advance nutrition and health'}

The Platform encompasses two Seminars: ENLP Seminar and ENLP Advanced Seminar. Both provide training on the qualities and skills of leaders, team building, communication of nutrition information in a broader context, and understanding the role of nutrition science in society. The Seminars are not focused on nutrition science, but on other skills and behavioural competencies, which leaders need to have. The courses are given by professional trainers in team building, communication and leadership.

The ENLP Seminar, targeted at ambitious nutrition scienists generally at the start of their career, has been held since 1994 . With 30 participants attending each year an active network of over 500 graduates from the programme was created. The programme is designed for ambitious final year PhD students and postdoctoral fellows or early-stage researchers in human nutrition science in Europe. Nutrition professionals with an MSc or PhD degree in nutrition or related sciences, who have several years of professional experience in the area of food/nutrition and health, are also invited to apply. Applications are welcome especially from countries which have been under-represented until now, e.g. the new EU member states in Eastern and Central Europe, and to a lesser extent the southern European countries. Non-European candidates may be selected if they intend to build up a career in Europe.

\section{ANNOUNCEMENT}

\author{
19th Seminar European Nutrition Leadership \\ Platform, Luxembourg \\ 17 April (arrival) to 25 April (departure) 2013 and
}

\section{2nd Advanced Seminar European Nutrition Leadership Platform}

Preference will be given to candidates under the age of 35 years. Thirty candidates will be selected by an independent international selection committee to attend the seminar. The 19th seminar will take place from 17-25 April 2013 at Hotel Parc Alvisse in Luxembourg.

ENLP Advanced is a highly practical Leadership Skills Programme specially designed for senior managers in the nutrition, food and health sectors who would like to further their career by developing or refreshing their commercial and leadership skills.

The ENLP Advanced Seminar is restricted to a maximum of 12 people, who will be selected by an independent international selection committee on the basis of their application. The 2nd ENLP Advanced seminar will take place from 21-25 April 2013 at Hotel Parc Alvisse in Luxembourg.

Both seminars are organised by a group of leading European nutritionists in close collaboration with and funded by the European food industry and a consortium of European universities and research institutes (ENABLE).

More information about fees and the application form for both seminars can be found on the website: www.enlp.eu.com.

Or contact the secretariat:

Mrs L.A. Duym, Division of Human Nutrition, Wageningen University, P.0. Box 8129, 6700 EV Wageningen, The Netherlands,

Tel. +31317 483054, Fax +31317 483342, E-mail: lous.duym@wur.nl

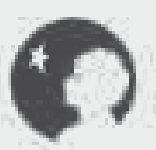

DSM 


\title{
Bridging the gaps between medicine, ethics, philosophy and religion
}

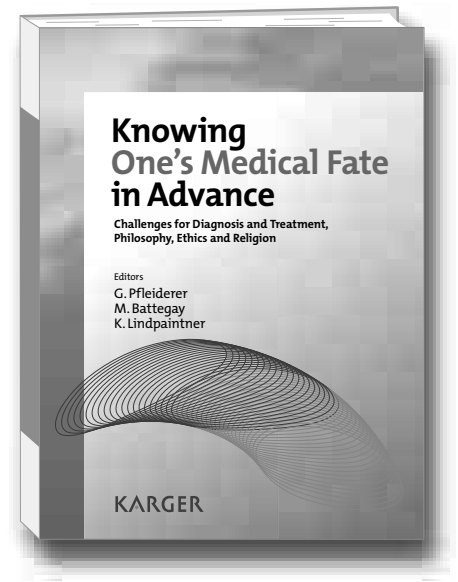

Modern medicine is now in a position to make advanced prognoses that chart the entire course of illness and recovery. Paradoxically, this is coupled with a new dimension of uncertainty for the patient, i.e. coming to terms with discovering they have an increased risk of a particular disease and deciding what appropriate steps to take. In this publication, renowned experts in their fields discuss these issues. The certainty and uncertainty of one's fate are discussed from both methodological and epidemiological perspectives, using examples of diseases for which treatment and prognosis have dramatically changed. Despite profound insights into the human genome, personalized genetically tailored medicine still lies in the future. Religious, spiritual and philosophical dimensions are discussed, as are the ways in which they may help people cope with these new insights into their future, e.g. the promise of an afterlife.

This publication aims to bridge the different fields dealing with this area by addressing the challenges faced and encouraging dialogue. It will be of interest to all readers who deal with ethical problems of prognosis, particularly in medicine, as well as to theologians and sociologists.

\section{Knowing One's Medical Fate in Advance}

\section{Challenges for Diagnosis and Treatment, Philosophy, Ethics and Religion}

\author{
Editors \\ Georg Pfleiderer \\ Manuel Battegay \\ Klaus Lindpaintner
}

\section{Contents \\ Introduction: Pfleiderer, G.; Battegay, M.; Lindpaintner, $K$.}

\section{Medical Perspectives}

- Evolving Therapy and Prognosis in HIV - How Knowing One's Medical Fate in Advance Can Change Dramatically: Battegay, $M$.

- Related to Human Cognition:

Is Personalization Feasible and Desirable? Papassotiropoulos, A.

Ethical and Juridical Perspectives

- Ethical Decision-Making on Genetic Diagnosis Facing the Challenges of Knowing One's Medical Fate in Advance: Brahier, G.

- Mastering Familial Genetic Knowledge: Shared or Secret? Issues of DecisionMaking in Predictive Genetic Testing: Brüninghaus, A.; Porz, $\boldsymbol{R}$.

- Predictive Medicine - Changes in Our View of Ourselves and Others: Birnbacher, $\boldsymbol{D}$.

- Current Challenges for the Law: Disclosure Dilemmas in Predictive Medicine: Dörr, B.S.
Religious Perspectives

- Fate and Judaism - Philosophical and Clinical Aspects: Gesundheit, B.

- Modern Medicine and My Future Life: A Christian-Theological Perspective: Pfleiderer, $G$.

- Karma, Contingency, and the 'Point of No Return': Predictive Medicine and Buddhist Perspectives: Schlieter, J.

\section{Author Index}

Subject Index
Knowing One's Medical Fate in Advance Challenges for Diagnosis and Treatment, Philosophy, Ethics and Religion

Editors: Pfleiderer, G.; Battegay, M. (Basel); Lindpaintner, K. (Newark, Del.) $\mathrm{VI}+122$ p., 4 fig., 2 in color, hard cover, 2012 CHF 59.- / EUR 49.- / USD 69.00

Prices subject to change

EUR price for Germany, USD price for USA only

ISBN 978-3-8055-9649-7

e-ISBN 978-3-8055-9650-3

\section{Please send: __ copy/ies}

E

Please charge to my credit card

- $\square$ American Express $\square$ Diners

ᄂ $\square$ MasterCard $\square$ Visa

- Card No.

$\boldsymbol{\sigma}$

$\nabla$

CVV/CVC

(3 digits in the signature field on the back of Visa and MasterCard)

$\square$ Check enclosed $\square$ Please bill me

Orders may be placed with any bookshop, subscription agency, directly with the publisher or through a Karger distributo
Fax: +41 613061234

S. Karger AG, P.O. Box, CH-4009 Basel (Switzerland) E-Mail orders@karger.ch, www.karger.com

Name/Address: 


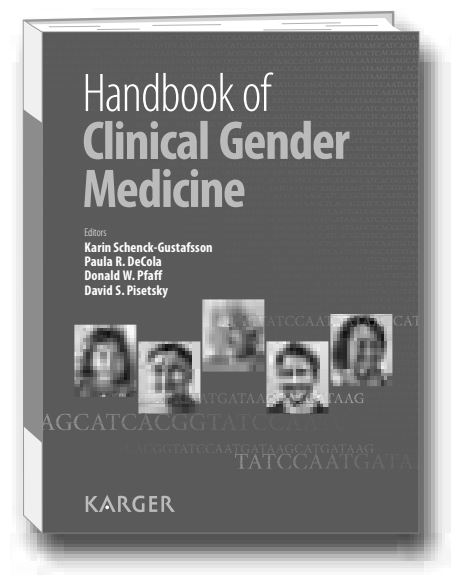

Gender medicine is an important new field in health and disease. It is derived from top-quality research and encompasses the biological and social determinants that underlie the susceptibility to disease and its consequences. In the future, consideration of the role of gender will undoubtedly become an integral feature of all research and clinical care.

Defining the role of gender in medicine requires a broad perspective on biology and diverse skills in biomedical and social sciences. When these scientific disciplines come together, a revolution in medical care is in the making. Covering twelve different areas of medicine, the practical and useful 'Handbook of Clinical Gender Medicine' provides up-to-date information on the role of gender in the clinical presentation, diagnosis, and management of a wide range of common diseases.

The contributing authors of this handbook are all experts who, in well-referenced chapters, cogently and concisely explain how incorporation of gender issues into research can affect the medical understanding and treatment of heart disease, osteoporosis, arthritis, pain, violence, and malaria among other conditions. This intriguing and unique medical textbook provides readers with a valuable new perspective to understand biology and incorporate gender issues into the different branches of medicine.

\section{Handbook of Clinical Gender Medicine}

\author{
Editors \\ Karin Schenck-Gustafsson \\ Paula R. DeCola \\ Donald W. Pfaff \\ David S. Pisetsky
}

\section{Contents}

Foreword: Wainer, J.; Wainer, Z.

Preface: Schenck-Gustafsson, $\boldsymbol{K}$.

\section{Introduction}

Gender Matters: Wainer, J.; Wainer, Z.

Biological Sex and the Genome: What Makes Us

Ourselves? Legato, M.J.

\section{Social and Biological Determinants in Health and Disease}

Section Editors: DeCola, P.R.; Schober, J.M.

\section{Central Nervous System and}

Clinical Applications

Section Editor: Pfaff, D.W.

\section{Neurology}

Section Editor: Olsson, $\boldsymbol{T}$.

Pain

Section Editor: Murphy, A.Z.

Circulation

Section Editor: Schenck-Gustafsson, $\boldsymbol{K}$.
Cancer

Section Editor: Gustafsson, J.-Å.

\section{Metabolic Disease}

Section Editor: Werner, $\mathbf{S}$.

\section{Autoimmune, Inflammatory, and}

Musculoskeletal Disease

Section Editor: Pisetsky, D.S.

\section{Infectious Diseases}

Section Editor: Britton, $\mathbf{S}$.

Urology, Sexual Dysfunction,

and Nephrology

Section Editor: Arver, $\mathbf{S}$.

\section{Pharmaceutical Drugs}

Section Editor: Parekh, $\boldsymbol{A}$.

\section{Geriatrics}

Section Editor: Herlitz, $\boldsymbol{A}$.

\section{KARGER}

Please see the full contents on:

www.karger.com/gender_medicine

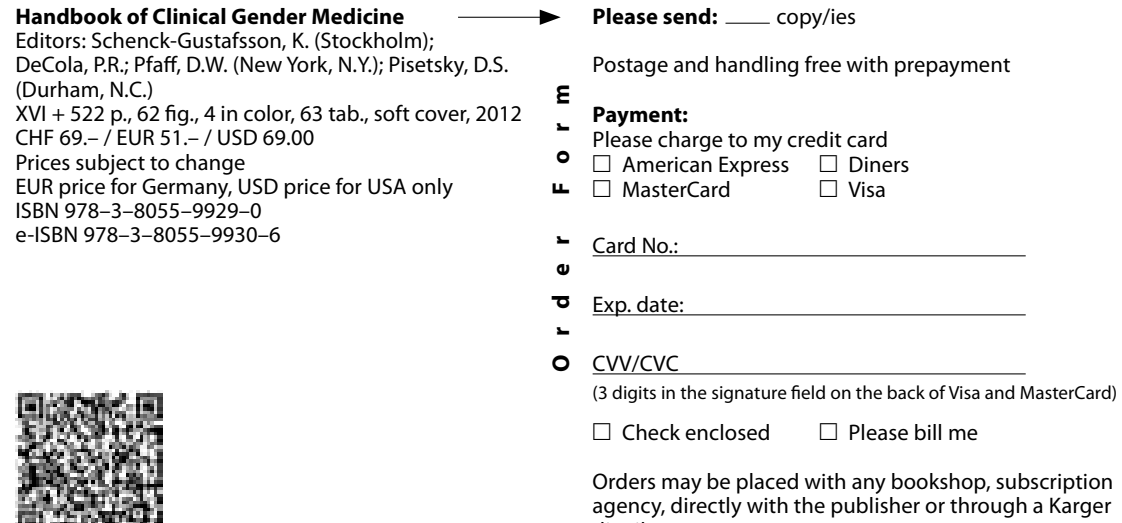

Handbook of Clinical Gender Medicine Editors: Schenck-Gustafsson, K. (Stockholm);

DeCola, P.R.; Pfaff, D.W. (New York, N.Y.); Pisetsky, D.S (Durham, N.C.)

$\mathrm{XVI}+522$ p., 62 fig., 4 in color, 63 tab., soft cover, 2012 CHF 69.- / EUR 51.- / USD 69.00

Prices subject to change

EUR price for Germany, USD price for USA only

ISBN 978-3-8055-9929-0

e-ISBN 978-3-8055-9930-6

Please send: _ _ copy/ies

Postage and handling free with prepayment

E Payment:

Please charge to my credit card

- $\square$ American Express $\square$ Diners

4 $\square$ MasterCard $\square$ Visa

- Card No.

$\boldsymbol{v}$

Exp. date:

- CVV/CVC

( 3 digits in the signature field on the back of Visa and MasterCard)

$\square$ Check enclosed $\square$ Please bill me

Orders may be placed with any bookshop, subscription agency, directly with the publisher or through a Karger distributor.
Fax: +41 613061234

S. Karger AG, P.O. Box, CH-4009 Basel (Switzerland) E-Mail orders@karger.ch, www.karger.com

Name/Address: 


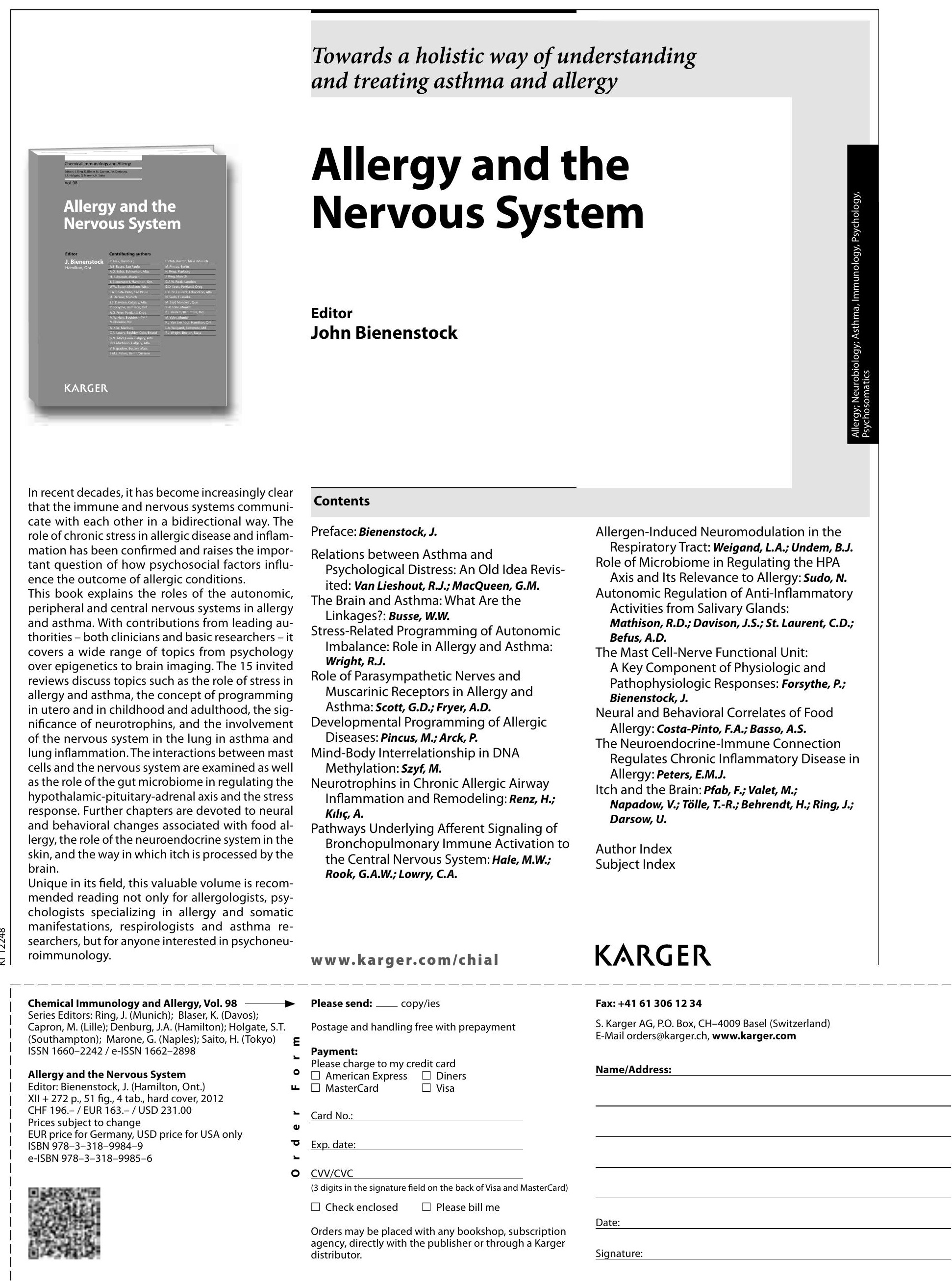




\section{Annals of Nutrition\& Metabolism}

An Official Journal of the

International Union of

Nutritional Sciences (IUNS)

feng Societies (FENS)

European Nutraceutical Association (ENA)

Deutsche Gesellschaft für Ernährung (DGE)
Editor

B. Koletzko, Munich

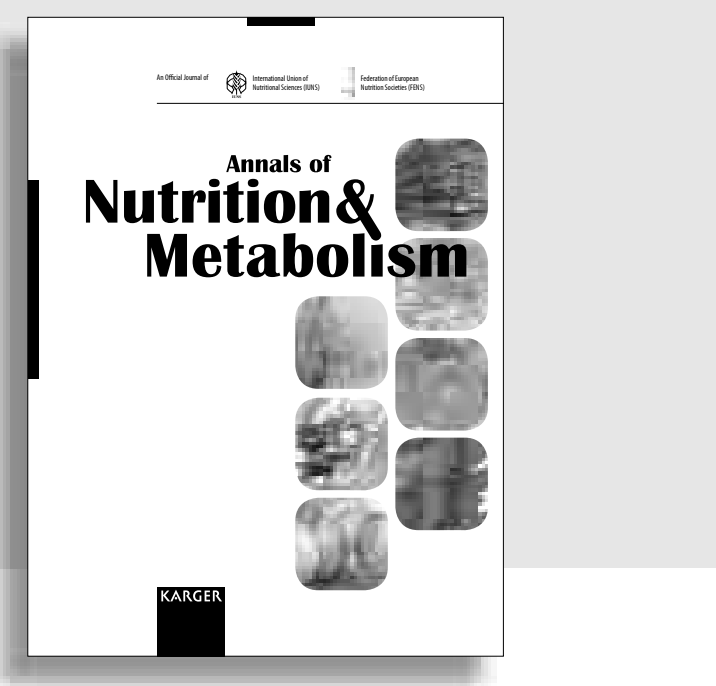

Annals of Nutrition and Metabolism is a leading international peer-reviewed journal for sharing information on human nutrition, metabolism and related fields, covering the broad and multidisciplinary nature of science in nutrition and metabolism. The journal focuses on human nutrition and metabolism and related areas, including experimental studies and basic science that can inform human nutrition science. We welcome manuscripts describing observational and intervention studies as well as basic science reports on the topics of foods, diets and dietary supplements, nutrigenomics and genetics related to metabolism, on energy metabolism, macro- and micronutrients including vitamins and minerals, biofunctional compounds, dietetics, obesity, clinical nutrition, social sciences and health economy as related to nutrition and metabolism and nutrition policy. Laboratorybased science may include descriptions of relevant experimental models. In addition to Original Papers, the journal will publish Review Articles on topical subjects, Systematic Reviews, short Commentaries and Viewpoint articles that may address current controversies, short Meeting Reports, Letters to the Editor, and Announcements/Society News. The journal will also publish Supplements with proceedings from internationally relevant conferences on nutrition and metabolism.

\section{Selected contributions}

Skeletal Muscle Metabolic Gene Expression Is Not Affected by Dichloroacetate-

Mediated Modulation of Substrate Utilisation: Tisdale, P.B.; Bennett, A.J.;

Seevaratnam, N.; Macdonald, I.A.; Tsintzas, K. (Nottingham)

Adherence to the Mediterranean Diet in Patients with Type 2 Diabetes Mellitus and HbA1c Level: Díez-Espino, J. (Tafalla); Buil-Cosiales, P.; Serrano-Martínez, M.; Toledo, E. (Pamplona); Salas-Salvadó, J. (Reus/Madrid); Martínez-González, M.Á. (Pamplona)

Effect of Vitamin A Deficiency on Iron Bioavailability: Mehdad, A.; Siqueira, E.M.A.; Arruda, S.F. (Brasilia)

The G Allele of Transcobalamin 2 c.776C $\rightarrow$ G Is Associated with an Unfavorable Lipoprotein Profile: Semmler, A. (Zürich/Bonn); Farmand, S.; Moskau, S.; Stoffel-Wagner, B. (Bonn); Linnebank, M. (Zürich/Bonn)

Blood Arachidonic Acid and HDL Cholesterol Influence the Phagocytic Abilities of Human Monocytes/Macrophages: Gutowska, I.; Baśkiewicz, M.; Machaliński, B.; Chlubek, D.; Stachowska, E. (Szczecin)

Epigenetic Control of Estrogen Receptor Expression and Tumor Suppressor Genes Is Modulated by Bioactive Food Compounds: Berner, C.; Aumüller, E.; Gnauck, A.; Nestelberger, M.; Just, A.; Haslberger, A.G. (Vienna)

Prepregnancy Body Mass Index and Resting Metabolic Rate during Pregnancy: Melzer, K. (Geneva); Schutz, Y. (Lausanne); Soehnchen, N.; Othenin Girard, V.; Martinez de Tejada, B.; Pichard, C.; Irion, 0.; Boulvain, M.; Kayser, B. (Geneva)

Physical Fitness and Obesity Are Associated in a Dose-Dependent Manner in Children: Ara, I. (Toledo/Zaragoza); Sanchez-Villegas, A. (Las Palmas de Gran Canaria); Vicente-Rodriguez, G.; Moreno, L.A.; Leiva, M.T. (Zaragoza); Martinez-Gonzalez, M.A. (Pamplona); Casajus, J.A. (Zaragoza)
More information at

\section{www.karger.com/anm}

- Pay-per-View and Subscriber Access to Full Text

- Full Table of Contents

- Full Editorial Board

- Free Abstracts and Selected Articles

- Online Sample Issue

- Submission/Guidelines for Authors

- Subscription Details

- Free Alert Service

- Online Library Recommendation

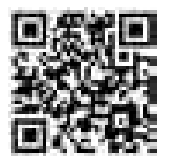

Annals of Nutrition and Metabolism 2012: Volumes 60, 61 4 issues per volume Language: English ISSN 0250-6807 (print) ISSN 1421-9697 (online)

Listed in bibliographic services, including Current Contents ${ }^{\oplus}$, MEDLINE, Biological Abstracts, EMBASE/Excerpta Medica 


\section{Karger Publications in Nutrition}

\section{World Review of Nutrition and Dietetics}

www.karger.com/wrund

Series Editor

B. Koletzko, Munich

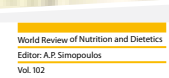

Healthy Agriculture, Healthy Nutrition,

Healthy People

A.P. Simopoulos

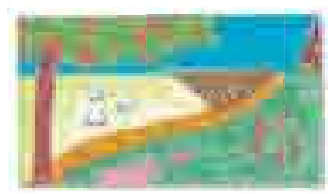

Vol. 102

Healthy Agriculture, Healthy Nutrition,

Healthy People (ISBN 978-3-8055-9779-1)

Vol. 101

Personalized Nutrition. Translating Nutrigenetic/ Nutrigenomic Research into Dietary Guidelines (ISBN 978-3-8055-9427-1)

Vol. 100

A Balanced Omega-6/0mega-3 Fatty Acid Ratio, Cholesterol and Coronary Heart Disease

(ISBN 978-3-8055-9224-6)

\section{Annals of Nutrition and Metabolism}

www.karger.com/anm

Current IF: 2.173

B. Koletzko, Munich

\section{Journal of Nutrigenetics and Nutrigenomics}

www.karger.com/jnn

Current IF: 1.304

Editor

J.X. Kang

Nestlé Nutrition Institute Workshop Series

www.karger.com/nniws

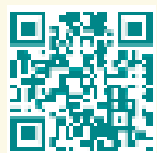

www.karger.com/nutrition

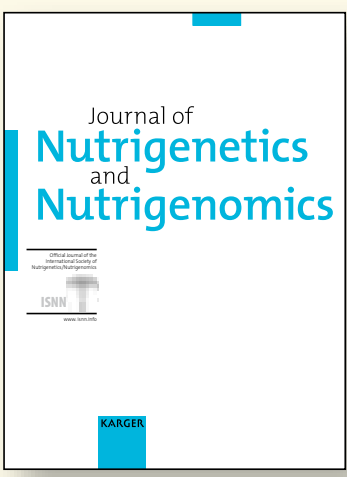

Official Journal of the

Awe International Society of

$\| S|N| N \mid$ Nutrigenetics/

Nutrigenomics (ISNN)
Association (ENA)

Deutsche

Gesellschaft für

Ernährung (DGE)
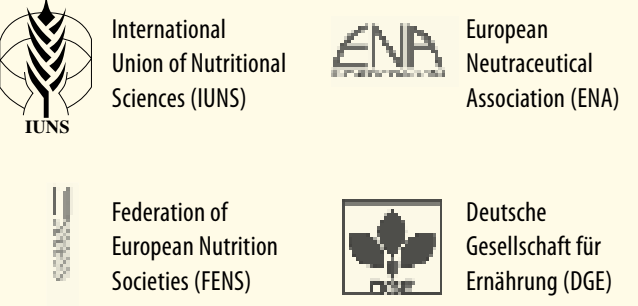

fens

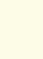

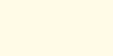

Official Journal of the

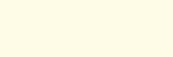

